\title{
Front Matter: Volume 10880
}

, "Front Matter: Volume 10880," Proc. SPIE 10880, Optical Elastography and Tissue Biomechanics VI, 1088001 (19 April 2019); doi: 10.1117/12.2523407

SPIE. Event: SPIE BiOS, 2019, San Francisco, California, United States 


\section{PROGRESS IN BIOMEDICAL OPTICS AND IMAGING}

\section{Optical Elastography and Tissue Biomechanics VI}

Kirill V. Larin

Giuliano Scarcelli

Editors

2-3 February 2019

San Francisco, California, United States

Sponsored by

SPIE

Cosponsored by

Thorlabs (United States)

Published by

SPIE 
The papers in this volume were part of the technical conference cited on the cover and title page. Papers were selected and subject to review by the editors and conference program committee. Some conference presentations may not be available for publication. Additional papers and presentation recordings may be available online in the SPIE Digital Library at SPIEDigitalLibrary.org.

The papers reflect the work and thoughts of the authors and are published herein as submitted. The publisher is not responsible for the validity of the information or for any outcomes resulting from reliance thereon.

Please use the following format to cite material from these proceedings:

Author(s), "Title of Paper," in Optical Elastography and Tissue Biomechanics Vl, edited by Kirill V. Larin, Giuliano Scarcelli, Proceedings of SPIE Vol. 10880 (SPIE, Bellingham, WA, 2019) Seven-digit Article CID Number.

ISSN: 1605-7422

ISSN: 2410-9045 (electronic)

ISBN: 9781510624023

ISBN: 9781510624030 (electronic)

Published by

SPIE

P.O. Box 10, Bellingham, Washington 98227-0010 USA

Telephone +1 3606763290 (Pacific Time) · Fax +1 3606471445

SPIE.org

Copyright (C) 2019, Society of Photo-Optical Instrumentation Engineers.

Copying of material in this book for internal or personal use, or for the internal or personal use of specific clients, beyond the fair use provisions granted by the U.S. Copyright Law is authorized by SPIE subject to payment of copying fees. The Transactional Reporting Service base fee for this volume is $\$ 18.00$ per article (or portion thereof), which should be paid directly to the Copyright Clearance Center (CCC), 222 Rosewood Drive, Danvers, MA 01923. Payment may also be made electronically through CCC Online at copyright.com. Other copying for republication, resale, advertising or promotion, or any form of systematic or multiple reproduction of any material in this book is prohibited except with permission in writing from the publisher. The CCC fee code is $1605-$ $7422 / 19 / \$ 18.00$.

Printed in the United States of America by Curran Associates, Inc., under license from SPIE.

Publication of record for individual papers is online in the SPIE Digital Library.

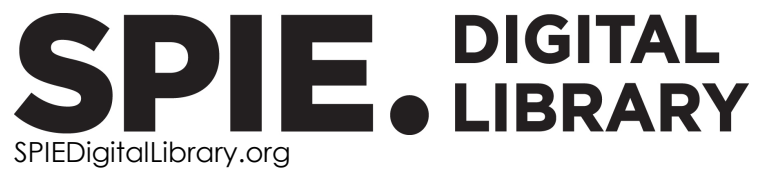

Paper Numbering: Proceedings of SPIE follow an e-First publication model. A unique citation identifier (CID) number is assigned to each article at the time of publication. Utilization of CIDs allows articles to be fully citable as soon as they are published online, and connects the same identifier to all online and print versions of the publication. SPIE uses a seven-digit CID article numbering system structured as follows:

- The first five digits correspond to the SPIE volume number.

- The last two digits indicate publication order within the volume using a Base 36 numbering system employing both numerals and letters. These two-number sets start with $00,01,02,03,04$, 05, 06, 07, 08, 09, 0A, OB ... 0Z, followed by 10-1Z, 20-2Z, etc. The CID Number appears on each page of the manuscript. 


\title{
Contents
}

\author{
$\checkmark \quad$ Authors \\ vii Conference Committee \\ xi Introduction
}

OPTICAL COHERENCE ELASTOGRAPHY I

1088003 Assessment of the biomechanical changes in cardiac tissue after myocardial infarction with optical coherence elastography [10880-2]

1088004 Correlation of optical coherence elastography with clinical evaluation of systemic sclerosis [10880-3]

1088007 Optimal frequency for vibrational optical coherence elastography (OCE) on tissue mechanical properties characterization [10880-6]

NOVEL METHODS I

10880 0G Perspectives and advances in optical elastography (Invited Paper) [10880-15]

$10880 \mathrm{OH} \quad$ Real-time and non-invasive quantitative phase imaging of pancreatic ductal adenocarcinoma cell mechanical properties [10880-16]

10880 OK Phase-sensitive OCT in monitoring of slow-rate strains in laser tissue reshaping [10880-19]

\section{OPTICAL COHERENCE ELASTOGRAPHY II}

$10880 \mathrm{OP}$ Differentiation of murine colon pathology by optical and mechanical contrast using optical coherence tomography and elastography [10880-24]

\section{BRILLOUIN ELASTOGRAPHY}

1088016 Sequentially-Shiffed Excitation (SSE) Brillouin spectroscopy for recovering signal contaminated with strong scattering, absorption or fluorescence [10880-41] 
10880 ID A preliminary study on using reverberant shear wave fields in optical coherence elastography to examine mice brain ex vivo [10880-48]

$10880 \mathrm{1H} \quad$ Evaluation of human corneal ulcer healing process using optical coherence tomography: an in vitro study [10880-52]

$1088011 \quad$ Adaptive Doppler analysis for robust handheld optical coherence elastography [10880-53]

$10880 \mathrm{lJ}$ OCE quantification of Poisson's ratio through 2D speckle tracking [10880-54]

$108801 \mathrm{~K}$ Simultaneous reconstruction and displacement estimation for spectral-domain optical coherence elastography [10880-55]

1088010 Assessing the effects of storage medium on the biomechanical properties of porcine lens with optical coherence elastography [10880-59]

10880 IP Quantifying lens elastic properties with optical coherence elastography as a function of intraocular pressure [10880-60] 


\section{Authors}

Numbers in the index correspond to the last two digits of the seven-digit citation identifier (CID) article numbering system used in Proceedings of SPIE. The first five digits reflect the volume number. Base 36 numbering is employed for the last two digits and indicates the order of articles within the volume. Numbers start with 00, 01, 02, 03, 04, 05, 06, 07, 08, 09, OA, OB...0Z, followed by 10-1Z, 20-2Z, etc.

Aglyamov, Salavat R., OP, 10, 1P

Assassi, Shervin, 04

Bagnaninchi, Pierre $\mathrm{O} ., \mathrm{OH}, 1 \mathrm{~K}$

Baum, O. I., OK

Canel, M., $\mathrm{OH}$

Das, Susobhan, OP

Du, Yong, OP

El Haj, A. J., $\mathrm{OH}$

El Haj, Alicia, $1 \mathrm{~K}$

Gamal, W., $\mathrm{OH}$

Garg, Harshita, $1 \mathrm{~J}$

Ge, Gary R., OG, 1D

Gelikonov, G. V., OK

Giannetto, Michael, 1D

Gillies, D., $\mathrm{OH}$

Huang, Zhihong, 07, 1H

Larin, Kirill V., 03, 04, OP, 10, $1 \mathrm{P}$

Larina, Irina $V_{\text {., }} 03$

Le, Triet, OP

Leach, John, 03

Li, Chunhui, 07, 1H

Ling, Yuting, $1 \mathrm{H}$

Liu, Chih-Hao, 03, 04, OP

Liv, Xuan, 11, 1J

Martin, James F., 03

Mason, Jonathan $\mathrm{H}$., $1 \mathrm{~K}$

Matveev, L. A., OK

Matveyev, A. L., OK

Mestre, Humberto, 1D

Mohan, Chandra, 04, OP

Nair, Achuth, OP

Nedergaard, Maiken, ID

Omelchenko, A. I., OK

Parker, Kevin J., OG, ID

Purslow, Christine, $1 \mathrm{H}$

Reinwald, Yvonne, $\mathrm{OH}, 1 \mathrm{~K}$

Rippy, Justin, 03

Rodriguez, Jonathan, $1 \mathrm{~J}$

Rolland, Jannick P., OG, ID

Schill, Alexander, 04

Serrels, A., $\mathrm{OH}$

Singh, Manmohan, 03, 04, OP, 10, IP

Smith, Christopher, 04

Sobol, E. N., OK

Soomro, Sanam, OP

Sovetsky, A. A., OK

Theodore, Samuel, 04

Troyanova-Wood, Maria, 16

Wang, Chizhong, 11
Wang, Jinjiang, 07

Wang, Ruikang, 07

Wang, Shang, 03

Wang, Yahui, 11

Waters, Sarah, $1 \mathrm{~K}$

Wu, Chen, IP

Yakovlev, Vladislav $\vee ., 16$

Yang, Ying, $\mathrm{OH}, 1 \mathrm{H}, 1 \mathrm{~K}$

Yuzhakov, A. V., OK

Zaitsev, V. Y., OK

Zaki, Farzana, 11, 1 J

Zhang, Duo, 07

Zhang, Hongqiu, 10, 1P

Zhou, Kanheng, 07

Zvietcovich, Fernando, OG, ID 
Proc. of SPIE Vol. $108801088001-6$

Downloaded From: https://www.spiedigitallibrary.org/conference-proceedings-of-spie on 26 Apr 2023 Terms of Use: https://www.spiedigitallibrary.org/terms-of-use 


\section{Conference Committee}

Symposium Chairs

James G. Fujimoto, Massachusetts Institute of Technology (United States)

R. Rox Anderson, Wellman Center for Photomedicine, Massachusetts General Hospital (United States) and Harvard Medical School (United States)

Symposium Co-chairs:

Jennifer K. Barton, The University of Arizona (United States)

Wolfgang Drexler, Medical University of Vienna (Austria)

Program Track Chairs

E. Duco Jansen, Vanderbilt University (United States)

Jessica C. Ramella-Roman, Florida International University

(United States)

Conference Chairs

Kirill V. Larin, University of Houston (United States)

Giuliano Scarcelli, University of Maryland, College Park (United States)

Conference Program Committee

Steven G. Adie, Cornell University (United States)

Jeffrey C. Bamber, Institute of Cancer Research (United Kingdom)

Albert Claude Boccara, Institut Langevin Ondes et Images (France)

Stephen A. Boppart, Beckman Institute for Advanced Science and Technology (United States)

Brett E. Bouma, Wellman Center for Photomedicine (United States)

Zhongping Chen, Beckman Laser Institute and Medical Clinic (United States)

Kishan Dholakia, University of St. Andrews (United Kingdom)

Christine P. Hendon, Columbia University (United States)

Davide Iannuzzi, Vrije Universiteit Amsterdam (Netherlands)

Brendan F. Kennedy, The University of Western Australia (Australia)

Sean J. Kirkpatrick, Michigan Technological University (United States)

Matthew O'Donnell, University of Washington (United States)

Amy L. Oldenburg, The University of North Carolina at Chapel Hill (United States) 
Gabriel Popescu, University of Illinois at Urbana-Champaign (United States)

Jannick P. Rolland, University of Rochester (United States)

David D. Sampson, University of Surrey (United Kingdom)

Ian A. Sigal, University of Pittsburgh (United States)

Gijs van Soest, Erasmus MC (Netherlands)

Kandice Tanner, National Cancer Institute (United States)

Peter Török, Imperial College London (United Kingdom)

Ruikang K. Wang, University of Washington (United States)

Vladislav V. Yakovlev, Texas A\&M University (United States)

Seok Hyun A. Yun, Harvard University (United States)

Vladimir Y. Zaitsev, Russian Academy of Science Nizhny Novgorod

(Russian Federation)

Qifa Zhou, The University of Southern California (United States)

\section{Session Chairs}

1 Optical Coherence Elastography I

Qifa Zhou, The University of Southern California (United States)

Brett E. Bouma, Wellman Center for Photomedicine (United States)

2 Cell Biomechanics

Jannick P. Rolland, University of Rochester (United States)

Matthew O'Donnell, University of Washington (United States)

3 Keynote Session

Kirill V. Larin, University of Houston (United States)

Giuliano Scarcelli, University of Maryland, College Park (United States)

4 Computation and Modeling

Sean J. Kirkpatrick, Michigan Technological University (United States)

Seok-Hyun Yun, Wellman Center for Photomedicine (United States)

Peter Török, Imperial College London (United Kingdom)

5 Novel Methods I

Ruikang K. Wang, University of Washington (United States)

Kishan Dholakia, University of St. Andrews (United Kingdom)

Christine P. Hendon, Columbia University (United States)

6 Optical Coherence Elastography II

Davide lannuzzi, Vrije Universiteit Amsterdam (Netherlands)

Vladimir Yu. Zaitsev, Russian Academy of Science Nizhny Novgorod

(Russian Federation)

David D. Sampson, University of Surrey (United Kingdom) 
7 Novel Methods II

Albert Claude Boccara, Institut Langevin Ondes et Images (France)

Stephen A. Boppart, Beckman Institute for Advanced Science and Technology (United States)

8 Biomechanics of the Eye

Steven G. Adie, Cornell University (United States)

Vladislav V. Yakovlev, Texas A\&M University (United States)

Gijs van Soest, Erasmus MC (Netherlands)

9 Brillouin Elastography

Zhongping Chen, Beckman Laser Institute and Medical Clinic (United States)

Brendan F. Kennedy, The University of Western Australia (Australia)

Amy L. Oldenburg, The University of North Carolina at Chapel Hill (United States) 
Proc. of SPIE Vol. 10880 1088001-10

Downloaded From: https://www.spiedigitallibrary.org/conference-proceedings-of-spie on 26 Apr 2023 Terms of Use: https://www.spiedigitallibrary.org/terms-of-use 


\section{Introduction}

This proceedings volume is from the Optical Elastography and Tissue Biomechanics $\mathrm{VI}$ conference held Saturday-Sunday, 2-3 February 2019, at SPIE BIOS, Photonics West, in San Francisco, California. Optical elastography can be broadly defined as the use of optics to probe and exploit the mechanical properties of cells and tissues including their ability to apply forces on the surrounding environment, as well as respond to forces of the surrounding microenvironment. The development of advanced optical techniques fits the larger context of tissue biomechanics studies where non-optical elastography techniques (ultrasound, magnetic resonance) have been established for many years as well as cell biomechanics research where the biological relevance of the mechanical metrics has triggered the development of many techniques such as atomic force microscopy, traction force microscopy, micropipette aspiration, particle rheology, and optical tweezers.

Many biological processes are strongly dependent on mechanical properties and forces at all scale, from sub-cellular organization to cellular function to tissue development to physiological and pathological behavior. As a result, a wide variety of contexts require different solutions to the evaluation of mechanical forces and mechanical properties of biological entities. In the past ten years, optical methods have emerged as important tools for these characterizations, both leading to clinically useful diagnostic and therapymonitoring methods and helping illuminate the important mechanical interactions occurring at cell and tissue scale. In addition, the information provided by optical methods is recently being incorporated with computational modeling efforts to accurately predict cell and tissue behavior.

This sixth annual conference continued the growth of the first five conferences and displayed a strongly multidisciplinary character, bringing together optical technology experts, clinical scientists, cell biologists, biophysicists, and biomechanics computational modeling experts. The meeting demonstrated increased attendance year to year. Also, this year, over 60 contributed papers were built around 2 days of talks and posters. Here are the keynote and invited talks of the program:

Keynote Presentation:

C. Ross Ethier, Georgia Institute of Technology (United States), "How imaging is informing diagnosis and treatment of glaucoma."

Invited Papers:

Assad A. Oberai, The Univ. of Southern California, (United States), "Linear and nonlinear optical coherence elastography in three dimensions."

Kandice Tanner, National Cancer Institute (United States), "High-frequency active microrheology in 3D reveals mismatch between tumor cell cytoskeletal and extracellular matrix mechanics."

Jannick P. Rolland, Univ. of Rochester (United States), "Perspectives and advances in optical elastography." 
Karol Karnowski, Institute of Physical Chemistry of the Polish Academy of Sciences (Poland), "Imaging of anterior segment pathologies: challenges and future opportunities."

J. Bradley Randleman, USC Roski Eye Institute (United States), "The importance of corneal biomechanics in clinical practice."

Darryl R. Overby, Imperial College London (United Kingdom), "Brillouin spectroscopy is insensitive to stiffness after correcting for the influence of water content in hydrogels."

Peter T. C. So, Massachusetts Institute of Technology (United States), "The application of interferometric imaging in quantitative mechanobiology."

Stefan Catheline, INSERM, Univ. of Lyon (France), "Passive elastography: from organ to cell."

The highlight of this year's meeting was the keynote lecture by Ross Ethier on the relevance of biomechanics in the diagnosis and treatment of glaucoma. Prof. Ethier is a biomechanicist and a glaucoma expert. After an overview on the biology of glaucoma, he reported his group's recent results establishing how outflow tissue stiffness reflects tissue function in glaucoma and optical coherence tomography methods to assess outflow tissue functional status. Special acknowledgement goes to Thorlabs Inc., whose sponsorship supported the keynote presentation.

Overall, this sixth annual conference continued to serve as a catalyst for the growth of the emerging area of optical technology development for cell and tissue biomechanical research. Several sessions also pointed at interesting developments to be expected in the next year. We hope you will enjoy the papers submitted for this volume.

\section{Kirill V. Larin Giuliano Scarcelli}

